\title{
Prof. Dr. Kertai Pál - egyetemi tanár
}

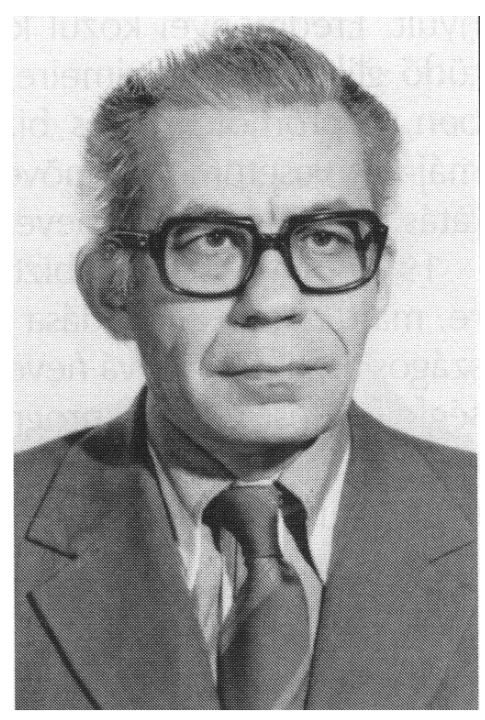

A debreceni temetóben, 2016. június 8-án 11 órakor több százan - kísértük végső nyughelyére Kertai Pál professzort, aki május 25 -én - 89 éves korában - váratlan hirtelenséggel távozott közülünk.

Több évtizedes személyes, baráti kapcsolat alakult ki Kertai professzor és az alulírott között a Debreceni Orvostudományi Egyetemen, ahová 1974-ben került a Közegészségtani és Járványtani Intézet élére.

Felejthetetlen emlékekként élnek bennem azok - a rendszerváltás utáni - órák, amelyeket az irodájában töltöttünk: Francia Istvánnal és a néhai Kövér András professzorral, amikor arról tárgyaltunk, hogy személye a legalkalmasabb az országban, hogy elnyerje az első országos tisztifóorvosi beosztást.

A szocializmusban kialakult nagyon helytelen egészségügyi kinevezési gyakorlat folytatódott 1990 után is, mert egészségügyi minisztereknek vagy államtitkároknak nem olyan személyek kerültek kinevezésre, akik komoly hazai vagy nemzetközileg elismert orvosi eredményekkel büszkélkedhettek (egyetlen pozitív kivétel volt Réthelyi Miklós professzor), hanem egyes személyek funkciókat kaptak, elfogadták azokat, de ók nem ismerték fel a saját korlátjaikat és így majdnem valamennyien - a magyar orvosi közvélemény szerint - súlytalanoknak bizonyultak.

Kertai Pál professzor esetében a funkció megtalálta Magyarországon az arra legalkalmasabb személyt. Több ezer előadást tartott, számos egyetemi jegyzetet jelentetett meg, és a „Közegészségtan” címú tankönyve három kiadást is megért $(1982,1986,1989)$. Több száz - a közegészségtan témához kapcsolódó - tudományos cikket publikált.
Kertai Pál Tótvázsonyban született 1927. december 20-án. Egyetemi tanulmányait a Budapesti Pázmány Péter Tudományegyetem Orvosi Karán 1951-ben fejezte be és szerzett orvosi diplomát. Ezt követôn az egyetem Kórélettani Intézetében, majd az Országos Közegészségtani Intézetben dolgozott az 1974-es debreceni kinevezéséig.

A kezdeti időszakban a fó kutatási területe a levegő és a víz szennyezőanyagainak, valamint a zajnak és az ionizáló sugárzásnak hatása volt a kísérleti állatok funkcióira, illetve a bakteriális endotoxinok hatása a neuroendokrin rendszerre. A debreceni periódusban kutatómunkája a kémiai rákokozók vizsgálatára, fóleg ezek gyors kimutatására irányult. Eredményei közül kiemelendő a kémiai karcinogének hatása az egértüdő glikolitikus enzimeire, a karcinogének perzisztálásának kimutatása egérben, a promoterhatás bizonyítása egértüdőben, a transzplantált leukémia máj- és vesetumorok növekedésének kvantitatív vizsgálata, a metasztáziskutatások új módszereinek bevezetése. Oktatási céljául túzte ki elméletben a közegészségtan tudományos alapjainak és társadalmi hátterének, gyakorlatban a Köjál (később ÁNTSZ) munkájának és laboratóriumi vizsgálatoknak ismertetését, valamint a gyakorló orvos betegségmegelőző munkájának népszerüsítését.

Amint már fentebb említettem, 1991-1995 között a Magyar Köztársaság első országos tisztifőorvosává nevezték ki. Korábban mint miniszteri biztos dolgozta ki a magyar egészségfejlesztési politika programját. Ez a funkció egész embert kívánt, állandó budapesti tartózkodást jelentett számára. A sors szeszélye következtében egyszerre kerültünk Budapestre (a IX. kerületbe), s innentől kezdve a barátságunk még jobban elmélyült. Rendszeresen, hetente találkoztunk és mindenról véleményt cseréltünk, mert Kertai Pál professzor nyitott volt a magyar társadalom minden kérdésére és igényelte, hogy megismerje az orvosi környezetének véleményét, a nem fönök-beosztott beszélgetések keretében is. Ez az állapot - Budapesten - 1995-ig tartott.

Ezt követően, visszatért a Debreceni Orvostudományi Egyetemre mint nyugdíjas, majd 1999-tól mint professor emeritus vett részt a Közegészségtani és Járványtani Intézet oktatói és kutatói munkájában. Kapcsolatunk nem szakadt meg, mert rendszeresen hosszan tartó telefonbeszélgetések formájában cseréltük ki gondolatainkat és évente 5-6-szor meglátogattam Debrecenben, ilyenkor legalább egy fél napot töltöttünk együtt „fejtágítás céljából”, hogy eszmét cseréljünk mindarról, amelyek 
érintették az országunknak és az emberiségnek a legfontosabb problémaköreit.

Kertai Pál professzor nagyra értékelte - az alulírott által szerkesztett - Emlékezünk orvosainkra sorozatot (e sorozatban eddig 32 kötet jelent meg), sőt aktív társszerzői szerepet is vállalt. Ő írt több - jelentős egészségügyi tevékenységet felmutató - elhunyt orvosról: Johan Béla, Belák Sándor, Jeney Endre, Mórik József.

Átadjuk a szót az elhunytnak, aki a „Ferencváros, mint a magyar orvosképzés fellegvára” címü kötetünkben (241-243. oldal) a következőképpen nyilatkozik az utóbbi évtizedek hazai közegészségügyéről:

„A változtatásokra a rendszerváltozást követően került sor. A Magyar Köztársaság első kormánya elhatározta egy korszerú - a közegészségügyet, a járványügyet és a társadalom-egészségügyet magában foglaló - népegészségügyi ellátó, szakfelügyeleti és szakirányítási intézményrendszer létrehozását.

Ennek az új intézményrendszernek - amelynek az 1991-ben született XI. törvény az »Állami Népegészségügyi és Tisztiorvosi Szolgálat « (ÁNTSZ) nevet adta alapvető célkitüzése az volt, hogy az országos tisztifőorvos vezetésével ismét helyreállítsa a két világháború között olyan jól múködő tisztiorvosi rendszert, átmentse és továbbfejlessze mindazokat a módszereket és eredményeket, amelyeket a II. világháború után a felügyelet elért, és biztosítsa a Gyáli út-Nagyvárad téren elhelyezkedő intézetek további múködését.

A kitűzött célok megközelítését a törvény elfogadása után elindították. Már az első hónapokban megtörtént a tisztiorvosi kar kinevezése, a tisztiorvosi tanfolyamok és vizsgák lebonyolítása, majd az elkövetkezó években a laboratóriumi munkálatok kiterjesztése, a molekuláris virológia meghonosítása, biztonsági laboratórium létesítése többek között a bioterrorizmus elleni védekezésre, és folytathatnánk a sort. Az újjászületett tisztiorvosi szolgálat múködésének köszönhetően a nyers halálozási arányszám 14\%o-ról 13\%o-re csökkent, a születéskor várható átlagos élettartam férfiak körében 6 , a nők körében 5 esztendővel növekedett.

Az elmúlt 20 esztendőben a felére csökkent az évente végzett múvi terhességmegszakítások száma, míg a csecsemóhalandóság, egy ország egészségügyének egyik legérzékenyebb mutatója, 15\%0-ről 5\%o-re esett vissza. Különösen sikeres a szolgálat munkássága a fertőző betegségek elleni küzdelemben. A védőoltások kiterjesztése, az elóírások szigorú betartatása, és a laboratóriumi háttér magas színvonala egyaránt azt eredményezte, hogy a fertözó betegségek halálozása terén Magyarország az Európai Unió egyik legjobb teljesitményt nyújtó országa lett.

Mindezek az eredmények kivívták a lakosság elismerését, és így történhetett, hogy 2009-ben egy közvélemény-kutatásban 26 állami intézmény közül az ÁNTSZ kapta a legmagasabb bizalmi pontszámot, maga mögött hagyva az Alkotmánybíróságot, a Legfelsőbb Ügyészséget és a helyi önkormányzatokat.
Aki a Nagyvárad téri és a Gyáli úti épülettömb környékén jár, kérem, gondoljon arra, hogy a magyar nép egészségügyének ez volt és részben $\mathrm{ma}$ is ez az intézmény a cselekvő központja. Ezekben az épületekben foglal helyet az Országos Tisztifóorvosi Hivatal, az Országos Epidemiológiai Központ, valamint a környezetegészségüggyel, a táplálkozás- és élelmezés-egészségügygyel, a kémiai biztonsággal és az egészségfejlesztéssel foglalkozó intézmények hivatalaikkal, információs rendszereikkel és laboratóriumaikkal együtt. Gondoljanak Johan Bélára és kiváló utódaira, akik hosszú évtizedeken keresztül igyekeztek megvalósítani az egyik legnagyobb magyar orvos, Fodor József álmait.

\section{Epilógus}

Álmomban ismét a Nagyvárad téren jártam, de szomorúan baktattam fel a metró lépcsőjén, mert eszembe jutott, hogy a tisztiorvosi szolgálatot az utóbbi néhány évben mennyi veszteség érte. Szakembereinek, laboratóriumainak, élelmezés-egészségügyi munkásságának jelentős, munkaegészségügyi tevékenységének egészét elvesztette, hatékony és könnyen áttekinthető szerkezete összezilálódott. De megszakadtak hagyományai is. A Gyáli utat, amely Johan Béla fáradozásainak köszönhetően több mint 85 éve ad otthont a magyar közegészségügynek és járványügynek és közben 40 egyetemi tanárt - köztük számos nemzetközileg elismert kutatót - adott a világnak, egy különben kiváló futballistáról nevezték el.

Az intézmény kertjéből pedig - kétes indokok alapján - központi utasításra eltávolították Johan Béla mellszobrát." (Megjegyzés: A Johan Béla-szobor - jelen cikk írójának - eredményes utánajárásának következtében, visszakerült az ÁNTSZ könyvtárának bejárata elé.)

Kertai Pál professzor nyomon követte munkatársainak szakmai fejlődését, akik mellőle kikerültek az ország legjelentősebb egyetemeire és kutatóintézeteibe. 1999-ben jelent meg a „Megelözö orvostan” címú könyve. Kertai professzor meghatározott ideig az MTA Egészségtudományi Bizottság elnöke, a Magyar Higiénikusok Társasága alelnöke, a Magyar Élettani Társaság vezetőségi tagja, a Népegészségügy föszerkesztője, a Journal of Hygiene, Epidemiology, Microbiology and Immunology, valamint az Egészségtudományi címú folyóiratok szerkesztóségi tagja volt.

Kiváló emberi tulajdonságokkal rendelkezett, udvarias volt mindenkivel, nem vesztette el türelmét a legnagyobb ostobaságok hallatán sem, és hihetetlenül szeretett oktatni, amit a legmagasabb szinten múvelt, az évtizedeken keresztül őt hallgató diákság megelégedésére.

A magyar közegészségügynek a legnagyobb élő ikonja volt, és távozásával nagyon sokat veszített a hazai orvostársadalom, mert véleményének a kiegyensúlyozottsága és a pozitív gondolkodásmód, amely jellemezte, egy hatalmas hiátus érzetét fogja eredményezni bennünk a közeli és a távolabbi jövőben is.

Prof. Dr. Vincze János Budapest 